\title{
CORRESPONDENGE
}

\section{The Interdisciplinary Management of Acute Chest Pain}

by Dr. med. Raphael R. Bruno, Prof. Dr. med. Norbert Donner-Banzhoff, Prof. Dr. med. Wolfgang Söllner, Prof. Dr. med. Thomas Frieling,

Prof. Dr. med. Christian Müller, and Prof. Dr. med. Michael Christ in issue $45 / 2015$

\section{Dangerous Statements}

In the CME article „The Interdisciplinary Management of Acute Chest Pain,“ the rule-in and rule-out criteria are presented within a proposed 1-hour algorithm (1). Dissemination of such criteria for the hs-cTnI assay (Dimension Vista, Siemens Healthcare) is highly dangerous, as there is no such assay on the market- the only available assay is several-fold less sensitive. While these criteria have been recently included in the European Guidelines, they have only been used with an assay intended for research that has never reached market maturity.

These statements are therefore dangerous, as physicians who work in hospitals, and whose laboratories are equipped with the Dimension Vista analysis system, may wrongly assume that the troponin I assay can be applied to the criteria. Within the daily routine, it can happen that not enough attention is paid to the units of the laboratory values (given here as ng/L), which could lead to fatal misjudgements. I have published a letter concerning this in „Clinical Chemistry and Laboratory Medicine“ (2).

I would kindly request that you correct this, as presenting this incorrect figure could have serious consequences for patients

DOl: 10.3238/arztebl.2016.0362b

\section{REFERENCES}

1. Bruno RR, Donner-Banzhoff N, Söllner W, Frieling T, Müller C, Christ $\mathrm{M}$ : The interdisciplinary management of acute chest pain. Dtsch Arztebl Int 2015; 112: 768-80.

2. Zur B, Stoffel-Wagner B: Misleading high-sensitivity troponin algorithm for NSTEMI in the ESC guidelines. Clin Chem Lab Med 2015; 53: e323.

PD Dr. med. Berndt Zur

Universitätsklinikum Bonn berndt.zur@ukb.uni-bonn.de

\section{Conflict of interest statement}

The author declares that no conflict of interest exists.

\section{REFERENCES}

1. Bruno RR, Donner-Banzhoff N, Söllner W, Frieling T, Müller C, Christ $M$ : The interdisciplinary management of acute chest pain. Dtsch Arztebl Int 2015; 112: 768-80.

2. How J, Volz G, Doe S, Heycock C, Hamilton J, Kelly C: The causes of musculoskeletal chest pain in patients admitted to hospital with suspected myocardial infarction. Eur J Intern Med 2005; 16: 432-6.

3. Ayloo A, Cvengros T, Marella S: Evaluation and treatment of musculoskeletal chest pain. Prim Care 2013; 40: 863-87.

4. Grgic V: Cervicogenic angina. Chest pain caused by unrecognized disc herniation at the segment C 6-C 7: a case report. Lijec Vjesn 2008: 130: 234-6.

Dr. med. Thomas Bambach

Neumarkt

dr-bambach-privat@gmx.de

\section{In Reply:}

We thank the authors for the numerous discussions initiated by our article „The Interdisciplinary Management of Acute Chest Pain“ (1). Our colleague Dr. Bambach refers to other important causes of acute chest pain, such as herpes zoster in its initial stage and additional distinct manifestations of skeletal and muscular problems, the clinical significance of which is widely accepted. Unfortunately, we could not address all of these important aspects due to limitations in the scope of our article. Many of the causes referred to by Dr. Bambach are in turn closely related to non-somatic causes of pain in general, and to chest pain in particular. For this reason, orthopedic surgeons and pain specialists should also be included in the treatment plan as a matter of course. 
Dr. Zur refers to the potential hazards associated with the clinical introduction of a 0-/1-h algorithm for evaluating acute chest pain (2). He points out that, in the current ESC guidelines (3), the hs-cTnI assay (Dimension Vista, Siemens Healthcare) mentioned for this algorithm is not currently commercially available in Germany and could possibly be confused with a distinct one that is on the market. We would like to explicitly affirm the importance of involving a competent specialist-in this case, a laboratory physician - when new algorithms are introduced to clinical routine and emergency diagnostics, to ensure a high level of patient safety. Meanwhile, a large multicenter prospective study of the algorithm proposed in the ESC guidelines has been prospectively validated for the hs-TnT assay (Roche Diagnostics) (4).

$$
\text { DOl: 10.3238/arztebl.2016.0362c }
$$

\section{REFERENCES}

1. Bruno RR, Donner-Banzhoff N, Söllner W, Frieling T, Müller C, Christ M: The interdisciplinary management of acute chest pain. Dtsch Arztebl Int 2015; 112: 768-80.
2. Zur B, Stoffel-Wagner B: Misleading high-sensitivity troponin algorithm for NSTEMI in the ESC guidelines. Clin Chem Lab Med 2015 53: e323.

3. Roffi M, Patrono C, Collet JP, et al.: 2015 ESC Guidelines for the management of acute coronary syndromes in patients presenting without persistent ST-segment elevation: Task force for the management of acute coronary syndromes in patients presenting without persistent ST-segment elevation of the European Society of Cardiology (ESC). Eur Heart J 2016; 37: 267-315.

4. Mueller $\mathrm{C}$, Giannitsis $\mathrm{E}$, Christ $\mathrm{M}$, et al.: Multicenter evaluation of a 0-hour/1-hour algorithm in the diagnosis of myocardial infarction with high-sensitivity cardiac troponin T. Ann Emerg Med 2016; pii: S0196-0644.

Dr. med. Raphael Romano Bruno

Prof. Dr. med. Michael Christ

Universitätsklinik der Paracelsus Medizinische Privatuniversität

Klinikum Nürnberg

Michael.Christ@klinikum-nuernberg.de

\section{Conflict of interest statement}

Prof. Christ has received consulting honoraria, reimbursement for scientific conference preparation, and research support (third-party funding) for both self-initiated projects, as well as for clinical trials conducted on their behalf, from Roche Diagnostics Alere GmbH and Philips GmbH.

Dr. Bruno declares that no conflict of interest exists. 